\title{
A NEW VARIETY OF SYNTRICHIA CANINERVIS (POTTIACEAE, MUSCI) НОВАЯ РАЗНОВИДНОСТЬ SYNTRICHIA CANINERVIS (POTTIACEAE, MUSCI)
}

\author{
Michael S. Ignatov ${ }^{1}$, Elena A. Ignatova ${ }^{2} \&$ Svetlana A. Suragina ${ }^{3}$ \\ МИХАИЛ С. ИГНАТОВ ${ }^{1}$, ЕЛЕНА А. ИГНАТОВА ${ }^{2}$ и СВЕТЛАНА А. СУРАГИНА ${ }^{3}$
}

Abstract

Syntrichia caninervis var. astrakhanica var. nov. is described from Astrakhan Province, where it was found in a number of localities, and also it is known from one place in Volgograd Province. The variety is peculiar in producing gemmae on long branched filaments, and they are typically clustered in great abundance at shoot tips. The more abundant are gemmae, the smaller are plants, and also leaves around gemmae have no hyaline hair-point and cells are weakly papillose to smooth and lamina is unistratose throughout. Variation in leaf shape is similar to that known in S. abrachesii (Luis.) Ochyra (Tortula caninervis var. abrachesii (Luis.) Kramer), which is known only from Spain.

Резюме

По сборам из Астраханской области описана новая разновидность, Syntrichia caninervis var. astrakhanica var. nov., которая, помимо ряда мест в этой области, известна и с юга Волгоградской обл. Данная разновидность отличается наличием выводковых круглых 2-4клеточных тел на длинных разветвленных нитях; их собрания часто скучены на верхушках побегов. Чем обильнее выводковые тела, тем меньше размер растений, листья вокруг собраний выводковых тел не имеют гиалинового волоска, пластинка однослойная, и клетки листовой пластинки слабо папиллозные до практически гладких. Изменчивость в форме листа несколько напоминает таковую, отмеченную для $S$. abrachesii (Luis.) Ochyra (Tortula caninervis var. abrachesii (Luis.) Kramer), известной только из Испании.

Studying bryophytes of the Lower Volga River, in Astrakhan Province (for climate and overall moss flora see Suragina \& al., 2002), we found a strange Pottiaceous moss, with short stems, terminated with the mass of 2-4celled dark red-brown gemmae. Gemmae are sitting on rhizoid-like colorless branched filaments, resembling those well known in Didymodon rigidulus Hedw. and D. cordatus Jur. However the plant has broad leaves, very different from those of Didymodon. Laminal cells were found variable from totally smooth to papillose.

Plants with abundant gemmae have mostly leaves with costa percurrent to very shortly excurrent. However the fact that these curious plants were found several times side by side with Syntrichia caninervis Mitt., which is rather polymorphic in this area, turned us to their detailed comparison. Soon we were succeeded to find some plants with less abundant gemmae and some leaves with costa excurrent in a hyaline hair-point. In most of such leaves with excurrent costa, the back of the latter is smooth, but sometimes it has few rather tall papillae, especially at the transition from lamina to hair point.

Checking more collections of "normal" $S$. caninervis from Astrakhan Province and southern part of neighbouring Volgograd Province (for its climate and overall moss flora see Suragina, 2001), we found in some of them a somewhat smaller plants with a few gemmae on filaments in leaf axils. The leaves around

1- Россия 127276 Москва, Ботаническая, 4, Главный ботанический сад РАН - Main Botanical Garden of Russian Academy of Sciences, Botanicheskaya, 4, Moscow 127276 Russia

2 - Россия 119899 Москва, Московский государственный университ, Биологический факультет - Moscow State University, Biological Faculty, Moscow 119899 Russia

3 - 400005 Волгоград, Ленина, 27, Волгоградский гос. пед. университет - Volgograd Pedagagical University, Lenina, 27, Volgograd 400005 Russia 


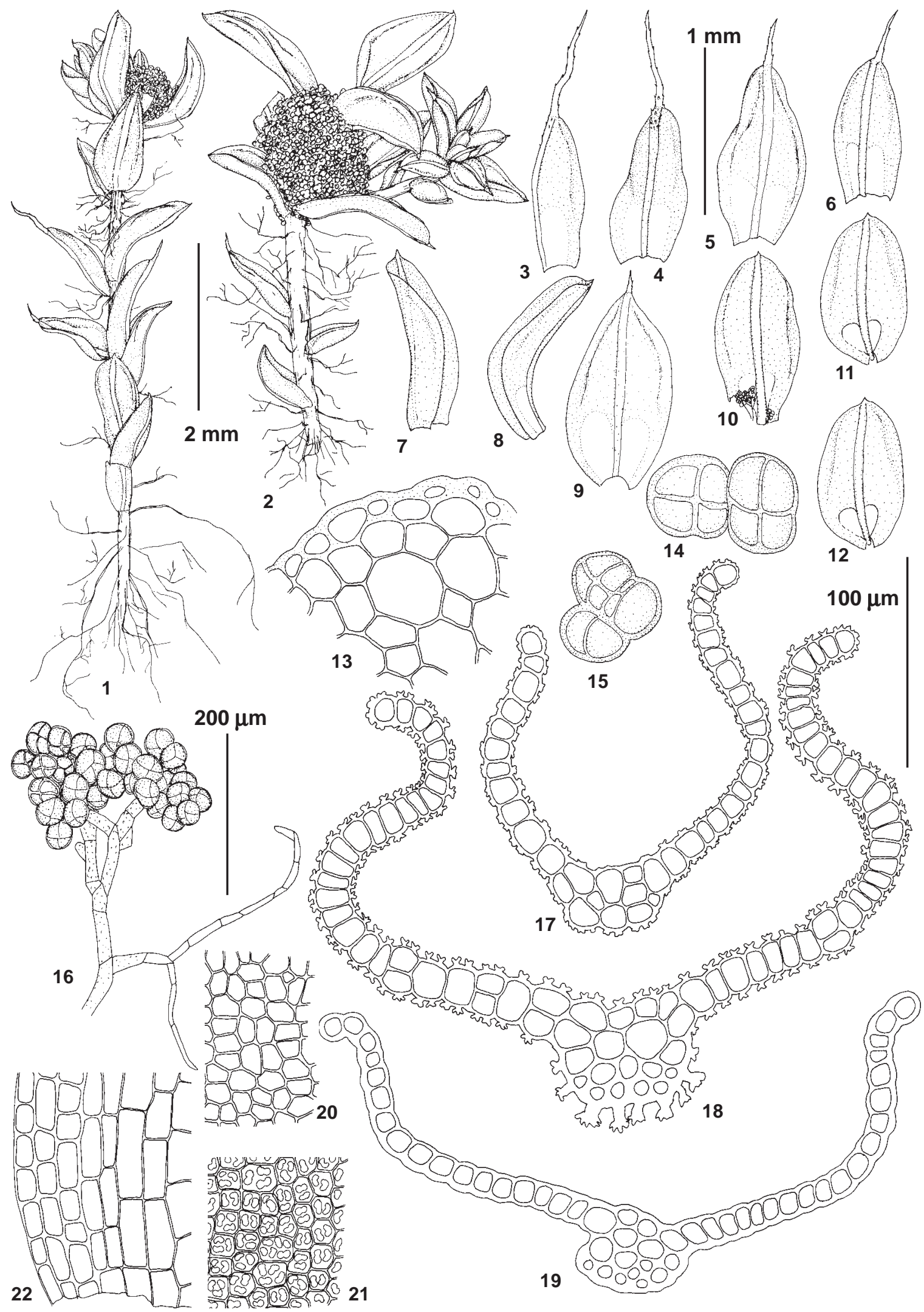


gemmiferous parts of shoots have always shorter hair-point (to almost none), unistratose lamina (or almost so) and less papillose laminal cells (to almost none). Thus, we left all the doubts that gemmiferous plants are an ultimate expression (probably a response to the most xerix environment) of $S$. caninervis.

The additional evidence to the conclusion that this curious moss belongs to $S$. caninervis is the similar tendencies to the loss of the hyaline hairpoint and to the low-papillose cells reported for Tortula caninervis ssp. spuria (Amman) Kramer var. gypsophila (Roth) Kramer [known from Central Europe and Middle East west to Afganistan] and especially var. abrachesii (Luis.) Kramer [known only from Spain] (see Kramer, 1980).

Very few species of Syntrichia were reported to produce gemmae. They occur regularly in S. latifolia (on upper lamina) and in $S$. rigescens and $S$. papillosa (on upper side of costa). In these 3 species however gemmae are always sessile (Kramer, 1980). An expanded search of any report of long-stalked gemmae in Syntrichia in literature (cf. Kramer, 1980; Mamatkulov, 1990; Zander, 1993; Crum \& Anderson, 1981; Mishler, 1994; Li, X.-j \& al., 2001; Smith, 1978; Savicz-Ljubitskaya \& Smirnova, 1970) gave no results. So, the plants under question represent probably the unique case of stalked gemmae in the genus.

The latter fact seems sufficient enough to describe these plants as a separate variety:

Syntrichia caninervis var. astrakhanica var. nov.

Holotype: Astrakhan Province, Bogdo Mountain, $48^{\circ} 09^{\prime} \mathrm{N}-46^{\circ} 50^{\prime} \mathrm{E}$, between Surikovskaya and Kordonnaya ravines, on sandy soil. Coll. Suragina, 2.V.2002 (MHA, isotype MW, VOLG, LE).

Plantae pro parte gemmiferae. Plantae non gemmiferae var. caninervis similes. Plantae cum gemmae valde minorae, folia mutica, celluli epapillosi.

Plants variable - partly gemmiferous, partly without gemmae. Latter approaching to $S$. caninervis var. caninervis, having stem $1-4 \mathrm{~cm}$ tall, leaves with long hyalyne hair-point, lamina partly bistratose, cells densely papillose. Among these tall plants spots with smaller plants situated (apparently in parts of tufts exposed to unfavorable environmental condition). Smaller plants in lax tufts or open groups, sometimes partly buried in sand, blackish-brown. Stem 2-10 mm long, lacking central strand and hyalodermis, loosely foliate, at base with long rhizoids, and in plants with many gemmae with subapical shoots, otherwise almost unbranched. Leaves when dry spreading, when wet widely spreading, 0.5-0.9 mm long, 0.2-0.5 $\mathrm{mm}$ wide (gradually becoming larger upwards), ovate to broadly elliptic, broadly acute to rounded, concave; margin widely recurved almost to apex, costa $40-60 \mu \mathrm{m}$ wide, usually of the same width in most of its length, in upper leaves percurrent to shortly excurrent and dorsally smooth, in lower leaves and leaves of subapical shoots - excurrent into hyaline hairpoint and dorsally moderately to highly papillose; on transverse section costa composed of rather homogeneous guide cells in 1-2 rows and substereid cells, without dorsal epidermis. Upper laminal cells isodiametric to irregularly polygonal, (12)18-20 $\mu \mathrm{m}$, in hair-pointed leaves papillose, in muticous leaves - lowly papillose to almost smooth; at base juxtacostal cells rectangular, 30-45 x 12-15 $\mu \mathrm{m}$, thin-walled; in leaves around numerous gemmae - mostly decomposed; basal cells at leaf margin shortly rectangular. Gemmae 2-4-celled, red-brown, spheric, 20-40 $\mu \mathrm{m}$, crowded distally on slightly to moderately branched filaments in leaf axils; abundant or a few (the more similar plant to var. caninervis, the fewer gemmae). Gametangia and sporophytes unknown.

Distribution and ecology: Besides the holotype this species has been found in several more places on Bogdo Hill and also in Astrakhan Province (1) near Kharabali town; (2) near Chapchachi railway station; and in Volgograd Province, near Tinguta. It is growing on soil, sand or gyps outcrops, sometimes in xeric, exposed habitats among steppe vegetation.

Fig. 1. Syntrichia caninervis var. astrakhanica Ignatov, Ignatova et Suragina, var. nov. (from Holotype: Bogdo, 2.V.2002 Suragina): 1-2 - habit; 3-12 - leaves; 13 - stem transverse section (from gemmiferous plant); 14-16 gemmae; 17-19 - leaf transverse sections (at the same part of leaf, in its middle part), showing variation from papillose to non-papilose; 20-21 - cells of mid-leaf, showing variation from papillose to non-papilose; 22 - basal cells. Scale bars: $2 \mathrm{~mm}$ for $1-2 ; 1 \mathrm{~mm}$ - for $3-12 ; 200 \mu \mathrm{m}$ - for $16 ; 100 \mu \mathrm{m}-13-15,17-22$ 


\section{ACKNOWLEDGEMENTS}

This study was partly supported by Russian
Foundation for Basic Researches, grants 02-0448358, 02-04-06499 and 02-04-63066.

\section{LITERATURE CITED}

CRUM, H. A. \& L. E. ANDERSON 1981. Mosses of the Eastern North America. - New York, Columbia University Press, $1328 \mathrm{pp}$.

KRAMER, W. 1980. Tortula Hedw. sect. Ruralis De Not. (Pottiaceae, Musci) in der östlichen Holarctis. - Bryph. Bibl. 21: 1-165+29 Tab.

LI, X.-J, S. HE \& Z. IWATSUKI 2001. Pottiaceae. - In: Li, X.-j. \& M. R. Crosby (eds. ), Moss flora of China, English version, Vol. 2. Fissidentaceae-Ptychomitriaceae. Science Press (Beijing, New York) and Missouri Botanical Garden (St. Louis): 114-249.

[MAMATKULOV, U. К.] МАМАТКУЛОВ, У. К. 1990. Флора мохообразных Таджикской ССР. - [The flora of the bryophytes of the Tadjik SSR] Душанбе, Дониш [Dushanbe, Donish], $236 \mathrm{pp}$.

MISCHLER, B. 1994. Tortula Hedw. - In: Sharp, A. J., H. Crum \& P. Eckel (eds.) The moss flora of Mexico. Mem. New York Bot. Garden. 69: 319-350.

[SAVICZ-LYUBITSKAYA，L.I. \& Z.N. SMIRNOVA]
САВИЧ-ЛЮБИЦКАЯ, Л.И., З.Н. СМИРНОВА 1970. Определитель листостебельных мхов CCCP. Верхоплодные мхи. - [Handbook of mosses of the USSR. The acrocarpous mosses] Л., Hаука [Leningrad, Nauka], 822.

[SMITH, A.J.E.] 1978. The moss flora of Britain and Ireland. - Cambridge, Cambridge. Univ. Press, 706.

[SURAGINA, S. А.] СУРАГИНА, С. А. 2001. Листостебельные мхи Волгоградской области (юго-Восток Европейской России). - Mosses of Volgograd Province (South-Eastern European Russia) Arctoa 10: 45-70.

[SURAGINA, S. A., E. A. IGNATOVA, M. S. IGNATOV \& V. I. ZOLOTOV] СУРАГИНА, С. А., Е. А. ИГНАТОВА, М. С, ИГНАТОВ, В. И. ЗОЛОТОВ 2002. Материалы к флоре мхов Астраханской области (Юг европейской России). - [Contribution to the Moss Flora of Astrakhan Province (South European Russia)] Arctoa 11: 169-174.

ZANDER, R. H. 1993. Genera of the Pottiaceae: mosses of harsh environments. - Bull. Buffalo Soc. Not. Sci. 32: 1-378. 